\title{
ANALISA ANTRIAN PENGERJAAN BENANG HEAT TECHNOLOGY DENGAN METODE JACKSON NETWORK DI PT. KURABO MANUNGGAL TEXTILE INDUSTRIES
}

\author{
Lenny Ratnasari ${ }^{1)}$, Yulizar Widiatama ${ }^{2)}$, Rully Nur Dewanti' ${ }^{2)}$ \\ ${ }^{1)}$ Mahasiswi Program Studi Teknik Industri, Universitas Pamulang \\ ${ }^{2)}$ Dosen Fakultas Teknik Program Studi Teknik Industri, Universitas Pamulang \\ dosen00898@unpam.ac.id
}

\begin{abstract}
ABSTRAK
PT.Kurabo Manunggal Textile Industries adalah salah satu perusahaan yang bergerak dibidang textile, dimana sebagian besar produksinya adalah benang heat technology. Masalah yang sering dihadapi adalah kurang efektifnya tenaga kerja dan mesin produksi, sehingga terjadinya bottleneck pada area packing. Untuk mencapai efisiensi kerja maka bottleneck harus diminimalkan dengan cara menyeimbangkan jumlah operator dan kecepatan mesin. Pada penelitian kali ini, penulis menganalisa sistem antrian yang ada pada area packing dengan metode Jackson Network, dan dengan menghitung performance mesin machconer dengan metode Overall Equipment Effectiveness. Hasil pengolahan data menunjukkan bahwa didapatkan waktu baku yang diperlukan untuk antrian sebesar 40 detik/bale jadi paling banyak 1 orang dapat melayani 3 sampai 4 mesin, dan untuk biaya layanan benang heat technology sebesar $R p$ 13.856,04/hari. Sementara biaya menunggu waktu packing sebesar $R p$ 83.810,69/hari. Sedangkan untuk nilai Overall Equipment Effectiveness diperoleh rata-rata sebesar 83,32\%. Peneliti juga melakukan asumsi simulasi antrian dengan waktu standar yang telah ditetapkan oleh perusahaan yaitu sebesar 2400 detik/bale. Dengan menggunakan asumsi waktu standar didapatkan hasil 26 bale/hari tanpa adanya over time. Selain itu, dengan melakukan perbandingan dan eksisting didapatkan perbedaan yaitu untuk rata-rata jumlah bale didapatkan 6 bale/hari, tidak ada waktu menunggu, jarak antrian lebih cepat 1515,789 detik, dan untuk lama packing lebih cepat 570 detik serta tidak ada over time.
\end{abstract}

Kata kunci: Antrian, Jackson Network, Overall Equipment Effectiveness

\section{PENDAHULUAN}

PT. Kurabo Mangunggal Textile Industries adalah salah satu perusahaan yang bergerak dibidang textile, dengan memproduksi benang dan kain. Namun, PT. Kurabo Manunggal Textile ini paling banyak memproduksi benang heat technology. Karena, benang heat technology adalah salah satu benang unggulan dari PT. Kurabo Manunggal Textile tersebut. Masalah yang sering dihadapi perusahaan adalah kurang efektifnya tenaga kerja dan mesin produksi, sehingga mengakibatkan terjadinya bottleneck pada salah satu stasiun kerja. Hal ini sangat mempengaruhi kinerja tenaga kerja dalam menghasilkan output yang diinginkan oleh pihak manajemen. Salah satu penentu kelancaran produktivitas adalah kelancaran proses produksi dan pemanfaatan sumber daya produksi yang efisien dan efektif, serta hal ini dapat dilihat pada kondisi antrian yang terjadi pada departemen packing benang heat technology, dimana antrian benang heat technology yang cukup menumpuk pada area packing yang menyebabkan bottleneck pada area packing tersebut. Untuk mencapai efisiensi kerja maka bottleneck harus diminimalkan salah satunya adalah dengan menyeimbangkan jumlah operator dengan kecepatan mesin pada penggulungan benang (winding). Oleh karena itu, perusahaan harus membenahi antrian yang terjadi di area packing sehingga tidak terjadi penumpukkan benang heat technology secara terus menerus. 
Maka dari itu, pada penelitian ini penulis berharap dapat memberikan masukan terhadap masalah yang dihadapi melalui analisa perhitungan dengan metode Jackson Network Infinite Queue Calling dan perhitungan Overall Equipment Effectiveness (OEE), serta penulis mencoba untuk mengungkapkan akar masalah dari sudut pandang penulis.

\section{LANDASAN TEORI}

\section{A. Teori Antrian}

Antrian dihasilkan dari permintaan sementara melebihi kapasitas layanan fasilitas, setiap kali pelanggan yang tiba tidak bisa menerima pelayanan segera karena semua server sibuk. Situasi ini hampir selalu terjadi di beberapa waktu dalam setiap sistem yang memiliki kedatangan probabilitik dan pola layanan teori antrian adalah teori yang menyangkut studi matematis dan barisbaris penungguan.

\section{B. Sistem Antrian}

Antrian timbul disebabkan oleh kebutuhan akan layanan melebihi kemampuan (kapasitas) pelayanan atau fasilitas layanan, sehingga pengguna fasilitas yang tiba tidak bisa segera mendapat layanan disebabkan kesibukan layanan.

\section{Jackson Network Queue}

Jackson Network Queue adalah salah satu algoritma yang berdasar pada antrian yang didahulukan pada setiap server. Output antrian akan diberikan pada antrian lainnya, setelah menerima layanan tertentu. Model ini dapat menganalisis dengan menggunakan proses birth-death multidimensional. Jackson Network Queue merupakan antrian dimana konsumen dapat berpindah dari satu workstation ke workstation lain beberapa kali sebelum meninggalkan sistem. Model antrian jaringan Jackson memberikan distribusi kesetimbangan gabungan sebagai produk dari distribusi kesetimbangan antrian individu.

\section{Definisi Overall Equipment Effectiveness}

OEE merupakan alat dalam program TPM yang digunakan untuk menjaga alat dalam kondisi ideal yang dikelompokan dalam tiga faktor OEE yaitu availability rate, performance rate, quality rate yang selanjutnya nilai dari ketiga faktor tersebut dapat dijadikan dasar perbaikan. Overral Equipmet Effectiveness (OEE) merupakan suatu ukuran seberapa efektif pabrik atau lini atau peralatan produksi dalam perusahaan dalam menghasilkan produk yang memenuhi standar kualitas sesuai waktu yang direncanakan.

\section{E. Kerangka Fikir}

Kerangka berfikir pada penelitian ini merupakan penjelasan dari suatu gejala objek permasalahan itu sendiri. Berikut uraian kerangka fikir yang digunakan dalam penelitian ini, dapat dilihat pada Gambar 2.1.

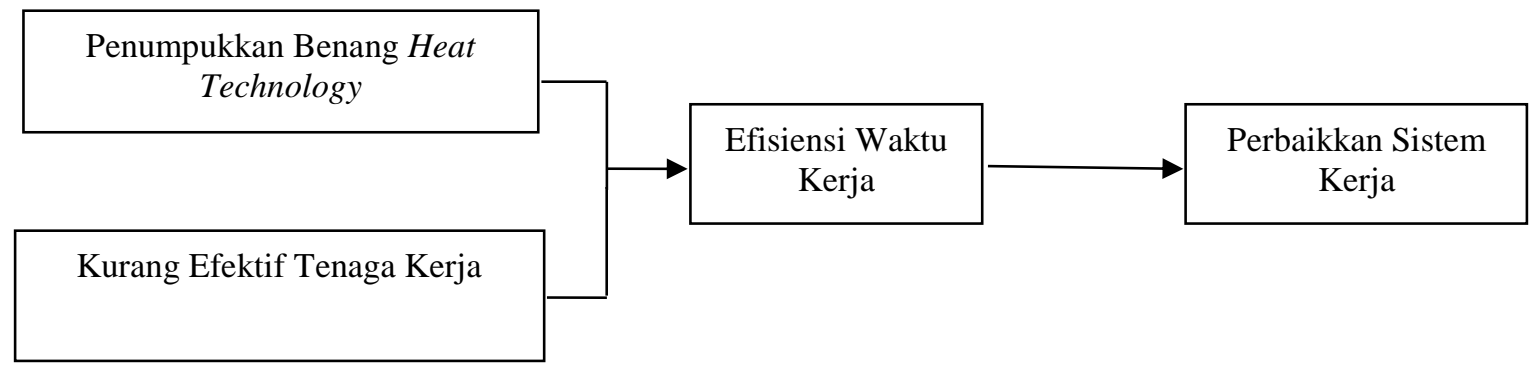

(Sumber: Hasil Pengolahan Sendiri)

Gambar 2.1 Kerangka Fikir 


\section{METODOLOGI PENELITIAN}

\section{A. Lokasi Penelitian}

Agar kegiatan penelitian ini dapat terfokus, maka ruang lingkup penelitian dibatasi berdasarkan tempat dan objek penelitian yaitu sebagai berikut:

1. Lokasi Penelitian

Penelitian ini dilakukan di PT. Kurabo Manunggal Textile Industries yang terletak di jalan MH. Thamrin No.1 Tangerang Banten.

2. Objek Penelitian

Pelaksanaan penelitian ini dilakukan pada waktu kedatangan kereta benang, waktu menunggu dan waktu proses packing benang heat technology, maka penulis membatasi penelitian ini hanya pada jenis produk itu saja yang proses produksi packing yang berada di pabrik satu.

\section{B. Jenis Penelitian}

Penelitian yang dilakukan termasuk penelitian deskriptif. Metode ini meneliti kondisi pada masa sekarang untuk membuat gambaran, deskripsi secara matematis dan jelas mengenai proses produksi yang berlangsung dan dapat digunakan untuk membuat rancangan perbaikan. Maka dari itu, untuk mencapai tujuan dari penelitian maka penulis menggunakan metode Jackson Network Queue yang digunakan untuk menghitung panjang antrian yang terjadi pada area packing, kemudian menentukan waktu kedatangan benang dan lamanya waktu menunggu benang sebelum di packing. Selain itu, membandingkan kondisi awal perusahaan pada produksi benang heat technology dengan metode yang digunakan oleh peneliti, lalu peneliti juga membuat simulasi dengan waktu standar yang telah ditetapkan oleh perusahaan.

\section{HASIL DAN PEMBAHASAN}

\section{A. Probabilitas Waktu Mengantri}

Perhitungan probabilitas waktu mengantri dalam penelitian ini menggunakan beberapa rumus yaitu:

$$
\begin{gathered}
P_{0}=\frac{1}{\sum_{n=0}^{c=1} \frac{(\lambda / \mu)^{n}}{n !}+\frac{(\lambda / \mu)^{c}}{c !(1-n / c \lambda)}} \\
P_{n}=\frac{\left(\frac{\lambda}{\mu}\right) n}{n !} \times P_{o} \quad \text { Jika } \mathrm{n} \leq \mathrm{c} \\
P_{n}=\frac{\left(\frac{\lambda}{\mu}\right) n}{C ! C^{n-c}} \times P_{o} \quad \text { Jika } \mathrm{n} \geq \mathrm{c}
\end{gathered}
$$

Dari hasil perhitungan probabilitas waktu mengantri dalam bulan April 2017 diperoleh nilai rata-rata probabilitas menunggu di sistem antrian adalah paling banyak 1 orang melayani 3 mesin.

\section{B. Rata-rata Banyaknya Pengantri Yang Sedang Antri (Lq) Dan Rata- Rata Waktu Antri (Wq)}

Perhitungan rata-rata banyaknya pengantri yang sedang antri (Lq) dan ratarata waktu antri (Wq) dihitung untuk mengetahui berapa banyak pengantri yang datang untuk mengantri dan dilayani.

Dari hasil perhitungan rata-rata banyaknya pengantri yang sedang antri dan rata-rata waktu antri selama bulan April 2017 didapatkan hasil perhitungan waktu normal yaitu pada tanggal 1 April $2017 P_{3.1}$ yaitu 39,416 detik atau 40 detik. Karena pada perhitungan probabilitas didapatkan hasil perhitungan paling banyak 1 orang melayani 3 sampai 4 mesin mesin. 


\section{Loading Time}

Loading time adalah waktu yang tersedia dalam dikurangi dengan planned downtime yang telah ditetapkan oleh manajemen perusahaan

Loading Time $=$ Available Time - Planned Downtime

Loading Time $=75.600-0=75.600$

Dari perhitungan loading time diperoleh rata-rata nilai sebesar 75600 detik. Hasil ini diperoleh dari rata-rata available time di kurang planned downtime. Namun, untuk planned downtime hasilnya adalah nol, karena untuk jam istirahat operator dibagi menjadi dua, sehingga mesin tetap berjalan ketika operator istirahat, hanya saja ketika shift pagi mesin berhenti sejenak karena adanya cleaning.

Downtime mesin merupakan waktu dimana mesin berhenti tidak melakukan operasinya karena adanya gangguan terhadap mesin. Dari perhitungan total downtime mesin dalam periode bulan April 2017 diperoleh ratarata sebesar 2.277,40 detik. Downtime mesin terbesar terjadi pada tanggal 1 mesin nomor 7 yaitu sebesar 6.300 detik, sedangkan downtime mesin terkecil terjadi di beberapa tanggal yaitu sebesar 1.500 detik.

\section{Avaibility Rate}

Availability rate adalah waktu pengoperasian mesin berdasarkan seberapa besar waktu yang dapat digunakan untuk produksi dari waktu yang tersedia (loading time) dikurangi downtime.

Availability Rate $=\frac{\text { Loading Time }- \text { Total Downtime }}{\text { Loading Time }} \times 100 \%$ Availability Rate $=\frac{75.600-4.140}{75.600} \times 100 \%=94,52$ $\%$

Rata-rata availability rate bulan April 2017 diperoleh sebesar 96,99\%, nilai availability rate terbesar yaitu $98,02 \%$ dan nilai availability rate terkecil diperoleh pada tanggal 1 dengan nomor mesin 7 dan tanggal 4 nomor mesin 6 sebesar 91,67\%. Untuk dapat menghitung availability rate harus diketahui terlebih dahulu berapa besarnya loading time dan downtime.

\section{E. Performance Rate}

Perhitungan Performance Rate (efficiency) yang pertama kali harus dihitung adalah Ideal Cycle Time yang merupakan waktu siklus ideal mesin saat beroperasi. Dalam perhitungan waktu siklus harus diketahui terlebih dahulu berapa persentase jam kerja yang dihitung dari waktu delay terhadap available time.

$\% \operatorname{Jam} \operatorname{Kerja}=1$

$$
\begin{aligned}
& -\left(\frac{\text { Total Delay }}{\text { Avaibility Time }}\right) \times 100 \% \\
\text { \% Jam Kerja }= & 1-\left(\frac{4.140}{75.600}\right) \times 100 \% \\
= & 94,52
\end{aligned}
$$

Perhitungan persentase jam kerja dibulatkan pada 2 angka dibelakang koma, rata-rata persentase jam kerja selama bulan April 2017 sebesar 98,99\% dengan nilai terbesar diperoleh sebesar $98,02 \%$ dan perolehan nilai terkecil terletak dibeberapa tanggal yaitu sebesar 91,67\%. Sebelum menghitung performance rate, maka harus dilakukan perhitungan Cycle Time terlebih dahulu berikut uraian perhitungan dapat dilihat dibawah ini.

Cycle Time $=\frac{\text { Loading Time }}{\text { Total Produksi }}$
Cycle Time $=\frac{75.600}{391}=193,35$

Ideal Cycle Time $=$ Cycle Time $\times$ Persentase Jam Kerja

Ideal Cycle Time $=193,35 \times 94,52=182,76$

Hasil perhitungan ideal cycle time dibulatkan pada 2 angka dibelakang koma. Nilai rata-rata ideal cycle time pada bulan April 2017 sebesar 247,09 
detik/cheese dengan nilai terbesar pada tanggal 8 nomor mesin 10 sebesar 837,21 detik/cheese dan nilai terkecil pada tanggal 12 nomor mesin 9 sebesar 118,75 detik/cheese.

Perhitungan performance rate dibulatkan pada 2 angka dibelakang koma, berikut uraian perhitungan performance rate.

Performance Rate $=\frac{\text { Good } \text { Product } \times \text { Ideal Cycletime }}{\text { Operation } \text { Time }}$

$\times 100 \%$

Performance Rate $=\frac{370 \times 182,76}{71.460} \times 100 \%=$ $94,63 \%$

Rata-rata perolehan performance rate pada bulan April 2017 sebesar $92,73 \%$ dengan perolehan tertinggi pada tanggal 29 dengan nomor mesin 9 sebesar $98,50 \%$ dan perolehan terendah terjadi di tanggal 9 nomor mesin 10 yaitu sebesar $83,04 \%$.

\section{F. Quality Rate}

Quality rate adalah perbandingan antara produk yang bisa diterima sesuai dengan standar mutu yang ditetapkan terhadap produk yang cacat atau tidak sesuai dengan kualitas mutu. Persentase perhitungan quality rate dibulatkan pada 2 angka dibelakang koma, berikut perhitungan quality rate.

Quality Rate $=\frac{\text { Good Product }}{\text { Total Product }} \times 100 \%$

Quality Rate $=\frac{370}{391} \times 100 \%=94,63 \%$

Good Product $=$ Total Product - Total Defect

Good Product $=391-21=370$

Dari perhitungan QR selama bulan April 2017 di peroleh rata-rata sebesar 92,73\% , dengan nilai QR terbesar pada tanggal 29 mesin No.9 yaitu 98,50\% dan nilai QR terkecil pada tanggal 9 mesin No.10 dengan nilai $83,04 \%$.

\section{G.Overall Equipment Effectiveness (OEE)}

Setelah perhitungan selesai selanjutnya dapat dihitung Overall Equipment Effectiveness (OEE) dengan mengalikan tiga faktor OEE yaitu availability rate, performance rate dan quality rate. Perhitungan nilai $\mathrm{OEE}$ dibulatkan pada 2 angka dibelakang koma.

OEE $=$ Avaibility Rate $(\%) \times$ Performance

Rate(\%) x Quality Rate(\%)

$O E E=94,52 \% \times 94,63 \% \times 94,63 \%=84,64 \%$

Hasil pengolahan dari data penelitian diperoleh nilai OEE rata-rata bulan April 2017 sebesar 83,47\% dengan nilai OEE tertinggi pada tanggal 29 nomor mesin 9 sebesar $95,10 \%$ dan nilai terkecil pada tanggal 9 nomor mesin 10 sebesar $65,68 \%$.

\section{H.Perhitungan Bobot Dan Pembagian Karyawan}

Setelah didapatkan nilai OEE dari masing-masing mesin, kemudian nilai OEE tersebut dijumlahkan dan di cari nilai rata-rata dari masing-masing mesin kemudian dijadikan desimal. Berikut perhitungan pembagian bobot berikut ini.

Bobot $=\%$ nilai $\mathrm{OE}$

$$
\begin{aligned}
& =81,59 \%=0,816 \\
& \text { Bobot }=\frac{\text { Rata }- \text { rata Nilai OEE }}{\text { Jumlah Rata }- \text { rata Nilai OEE }} \\
& \text { Bobot }=\frac{0,816}{8,096}=0,101
\end{aligned}
$$

Setelah didapatkan hasil dari perhitungan nilai bobot, kemudian dilanjutkan dengan perhitungan dalam pembagian karyawan. Berikut perhitungan untuk pembagian karyawan dapat dilihat pada Tabel $\mathbf{4 . 1 6}$ berikut ini: 
Tabel 4.16 Pembagian Karyawan

\begin{tabular}{|c|c|}
\hline Hasil & $\begin{array}{c}\text { Pembagian } \\
\text { Karyawan }\end{array}$ \\
\hline 0,101 & \multirow{3}{*}{0,299} \\
\hline 0,099 & \\
\hline 0,100 & \\
\hline 0,099 & \multirow{3}{*}{0,294} \\
\hline 0,099 & \\
\hline 0,097 & \\
\hline 0,096 & \multirow{4}{*}{0,407} \\
\hline 0,107 & \\
\hline 0,106 & \\
\hline 0,097 & \\
\hline
\end{tabular}

(Sumber: Hasil Pengolahan Sendiri)

Dari hasil perhitungan pembagian karyawan dengan menjumlahkan nilai bobot lalu dibagi 3, didapatkan hasil untuk operator packing dapat melayani 3 sampai 4 mesin setiap harinya.

\section{Perhitungan Total Biaya}

Adapun perhitungan total biaya per satuan waktu berdasarkan total biaya per satuan waktu/Expected Total Cost per unit time (ETC), satuan biaya layanan/Expected Service Cost per unit time (ESC), dan biaya menunggu per satuan waktu/Expected Waiting Cost per unit time (EWC). Berikut perhitungan total biaya pada bulan April 2017.

1. Total Biaya Per Satuan Waktu (ETC)

Total biaya didapatkan dari hasil ratarata waktu packing dikalikan dengan biaya tenaga kerja per detik, lalu dibagi dengan waktu standar packing yang ditetapkan oleh perusahaan.

$$
\begin{aligned}
2400 \mathrm{x} & =\operatorname{Rp} 5,29 \times 2970 \mathrm{~S} \\
\mathrm{X} & =\frac{R p 5,29 \times 2970}{2400}=\operatorname{Rp} 6,55
\end{aligned}
$$

/ detik

Dari hasil perhitungan expected total cost per unit time didapatkan hasil sebesar Rp 173,20 per detik (Seratus tujuh puluh tiga koma dua puluh rupiah).
2. Satuan Biaya Layanan (ESC)

Satuan biaya layanan merupakan hasil dari rata-rata waktu packing, kemudian dikalikan dengan biaya kerja per detik. Berikut uraian perhitungan satuan biaya layanan.

ESC = Rata-rata Waktu Packing $\mathrm{x}$ Biaya Per Detik

$$
\begin{aligned}
& =2970 \times \operatorname{Rp~5,29} \\
& =\operatorname{Rp~15.714,27~}
\end{aligned}
$$

Dari hasil perhitungan satuan biaya layanan (ESC) didapatkan rata-rata pelayanan selama 1 bulan $\mathrm{Rp}$ 13.856,04/bale. (Tiga belas ribu delapan ratus lima puluh enam rupiah).

3. Biaya Menunggu Per Satuan Waktu (EWC)

Biaya menunggu per satuan waktu didapatkan dari hasil perhitungan waktu menunggu kereta benang dihitung pada saat jam masuk kerja packing sampai dengan dilayanani/dipacking.

Biaya EWC = Waiting Time $\mathrm{x}$ Biaya TK Langsung

$$
\begin{aligned}
& =300 \times \operatorname{Rp~5,29} \\
& =\operatorname{Rp} 1.587,30
\end{aligned}
$$

Dari hasil perhitungan biaya menunggu perhitungan per satuan waktu (EWC) didapatkan hasil biaya waktu menunggu per hari dalam periode April 2017 sebesar Rp $83.810,69 /$ hari. Jadi dalam waktu sebulan perusahaan mengalami kerugian sebesar Rp 83.810,69/hari (Delapan puluh tiga ribu delapan ratus sepuluh rupiah).

\section{J. Simulasi Perhitungan Dengan Waktu Standar}

Simulasi perhitungan dengan
waktu standar digunakan untuk
menentukan antrian, dan untuk waktu
proses packing menggunakan standar
yang telah ditetapkan oleh perusahaan
yaitu sebesar 40 menit atau 2400 detik.


Kemudian, untuk waiting time menggunakan perhitungan dimulai dari waktu standar dapat dilihat pada Tabel nol. Berikut perhitungan simulasi dengan 4.20.

Tabel 4.20 Simulasi Antrian Dengan Waktu Standar

\begin{tabular}{|c|c|c|c|c|c|c|c|}
\hline No & $\begin{array}{c}\text { Waktu Kedatangan } \\
\text { Per Bale }\end{array}$ & $\begin{array}{c}\text { Qty } \\
\text { Input }\end{array}$ & $\begin{array}{c}\text { Waiting Time } \\
\text { (Detik) }\end{array}$ & $\begin{array}{c}\text { Service } \\
\text { Time } \\
\text { (Detik) }\end{array}$ & $\begin{array}{c}\text { Service } \\
\text { Time } \\
\text { (menit) }\end{array}$ & $\begin{array}{c}\text { Finish } \\
\text { Time }\end{array}$ & $\begin{array}{c}\text { Waktu Pada } \\
\text { Sistem (Detik) }\end{array}$ \\
\hline 1 & 06.40 & 3 & 0 & 7.200 & 120 & 08.40 & 7.200 \\
\hline 2 & 06.40 & 3 & 0 & 7.200 & 120 & 08.40 & 7.200 \\
\hline 3 & 06.40 & 4 & 0 & 9.600 & 160 & 09.20 & 9.600 \\
\hline 4 & 08.40 & 3 & 0 & 7.200 & 120 & 10.40 & 7.200 \\
\hline 5 & 08.40 & 3 & 0 & 7.200 & 120 & 10.40 & 7.200 \\
\hline 6 & 08.40 & 4 & 2400 & 9.600 & 160 & 12.00 & 12.000 \\
\hline 7 & 10.40 & 3 & 0 & 7.200 & 120 & 12.40 & 7.200 \\
\hline 8 & 10.40 & 3 & 0 & 7.200 & 120 & 12.40 & 7.200 \\
\hline
\end{tabular}

(Sumber: Hasil Pengolahan Data)

Dari hasil simulasi dengan waktu standar yaitu 2400 detik, dan dengan asumsi kereta datang setiap bale di waktu yang sama dan dilayani di waktu yang sama pula didapatkan hasil yang cukup optimal, dimana operator memegang 3 sampai 4 mesin sesuai dengan perhitungan bobot yang sebelumnya telah dihitung. Dalam simulasi ini waktu kedatangan per bale dengan waktu yang sama dan tanpa adanya over time, diasumsikan dalam setiap 2400 detik mendapatkan 10 bale benang heat technology. Jadi dalam 1 hari operator packing harus melayani paling tidak 26 bale benang heat technology.

Berikut perbandingan antara hasil simulasi waktu standar dengan pembahasan, dapat dilihat pada Tabel 4.21 berikut ini.

Tabel 4.21 Perbandingan Simulasi Antrian Dengan Eksisting

\begin{tabular}{|c|c|c|c|}
\hline Keterangan & Simulasi & Eksisting & Perbedaan \\
\hline Rata-rata Jumlah Bale/hari & 26 & 20 & 6 \\
\hline Waktu Menunggu & 0 & 229500 & Tidak ada waktu menunggu \\
\hline Jarak Antar Antrian & 2.400 & 3915,789 & 1515,789 detik \\
\hline Lama Packing & 2.400 & 2970 & Lebih cepat 570 detik \\
\hline OT & 0 & 0 & Tidak ada OT \\
\hline Waktu Kerja (Detik) & 25.200 & 25200 & \\
\hline
\end{tabular}

(Sumber: Hasil Pengolahan Data)

Dari hasil perbandingan antara hasil simulasi dengan pembahasan didapatkan hasil perbedaan yaitu untuk rata-rata jumlah bale mendapatkan 6 bale/hari, tidak ada waktu menunggu, jarak antar antrian lebih cepat 1515,789 detik, dan untuk lama packing lebih cepat 570 detik serta tidak ada over time.
Selain itu, dengan adanya perhitungan OEE penulis dapat mengetahui bahwa banyak atau sedikitnya hasil produksi selain karena adanya putus benang, hal itu juga dipengaruhi karena downtime yang terjadi pada mesin tersebut. Dimana hasil OEE yang cukup rendah juga dikarenakan downtime yang 
terjadi pada mesin mach coner karena adanya kerusakan pada mesin mach coner tersebut. Kerusakan yang paling banyak terjadi pada mesin mach coner yaitu karena adanya splacer lemah, dan untuk pergantian spare part paling tidak dilakukan antara 20 sampai 50 menit. Untuk perawatan mesin mach coner sendiri harus dilakukan penelitian mendalam yang disesuaikan dengan variabel, dimensi dan indikator keandalan mesin tersebut, hal ini dilakukan untuk mengetahui masalah yang apa saja yang terjadi pada mesin mach coner tersebut, lalu selanjutnya dilakukan perbaikkan pada mesin tersebut.

\section{KESIMPULAN}

Berdasarkan hasil analisis dan hasil perhitungan dari sistem antrian Jackson Network Infinite Queue Calling, maka dapat diambil beberapa kesimpulan yaitu sebagai berikut:

1. Dengan mengaplikasikan teori Jackson Network Infinite Queue Calling didapatkan waktu baku yang diperlukan untuk antrian yaitu sebesar 40 detik. Sedangkan untuk biaya layanan packing benang heat technology didapatkan hasil rata-rata sebesar Rp 13.856,04/bale, dan dengan asumsi waktu antri dengan waktu standar yang telah ditetapkan perusahaan yaitu 2.400 detik /bale mendapatkan 26 bale setiap harinya tanpa adanya over time.

2. Dengan menerapkan teori Jackson Network Infinite Queue Calling didapatkan hasil dari perhitungan probabilitas dan rata-rata waktu antri yaitu paling banyak 1 orang melayani 3 mesin. Hal ini juga dapat dilihat pada perhitungan efisiensi mesin dengan nilai OEE rata-rata yaitu $83,32 \%$. Untuk nilai OEE sendiri tergolong cukup rendah karena hal ini disebabkan oleh putus benang dari mesin tersebut. Selain itu, dengan melakukan perbandingan antara simulasi dengan eksisting didapatkan perbedaan yaitu untuk rata-rata jumlah bale mendapatkan 6 bale/hari, tidak ada waktu menunggu, dan untuk lama packing lebih cepat 570 detik serta tidak ada over time.

\section{DAFTAR PUSTAKA}

Ansori, Nachnul. Muhamad Imron Mustajib. 2013. Sistem Perawatan Terpadu. Graha Ilmu. Yogyakarta.

Damayanti, Desi. 2015. Analisis Performansi Server Sistem Informasi Akademik Universitas Mercu Buana Dengan Open Queuing Network. Program Studi Teknik Informatika, Fakultas Ilmu Komputer. Jakarta.

Darmawan, Gumgum. 2015. Simulasi mAntrian Jackson Enam Workstation Dengan Menggunakan Matriks Peluang Transisi Yang Berbeda. Bandung.

Pitono, Teguh. 2011. Analisis Efektivitas Mesin Extruder Dengan Metode Overall Equipment Effectiveness (OEE) Untuk Perbaikan Proses Di PT. Sinta Prima Feedmill. Universitas Pamulang. Tangerang Selatan.

Puspaningrum, Varisa. 2016. Implementasi Sistem Jaringan Jackson Network Pada Prototype Antrian Rumah Sakit. Jurusan Ilmu Komputer Fakultas Matematika dan Ilmu Pengetahuan. Universitas Lampung.

Rico, Andrian, dkk. 2016. Implementasi Sistem Antrian Jaringan Jackson Network Pada Rumah Sakit. Universitas Lampung

Siswanto. 2007. Operation Research Jilid 2. Erlangga. Yogyakarta. 
Wandhawa, Nandhika Putra Harahap, dkk. 2013. Analisis Dan Perancangan Decision Support System Untuk Melakukan Prediksi Dan Melihat Kondisi Antrian Mahasiswa Berdasarkan Metode Queuing Teori Dan Forecasting. Universitas Bina Nusantara. 